\title{
De vele lichamen die we zijn Medisch-wijsgerige verkenningen
}

B. Sabbe, L. Braeckmans
239 blz., Gompel \& Svacina, 2020 (ISBN 978-94-6371-227-9)

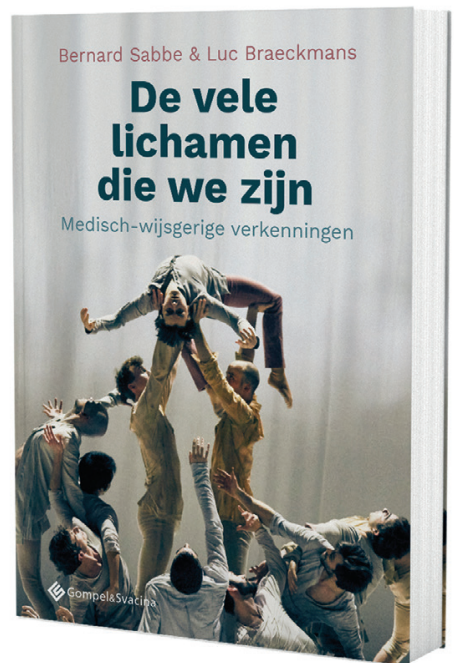

Wanneer een emeritus psychiater en een emeritus filosoof zich samen aan het schrijven zetten, moet dit wel vonken geven. Zoals de auteurs stellen in hun inleiding: in deze tijd van multidisciplinaire samenwerking gebeurt het nog al te zelden dat stukken van de puzzel worden samengelegd in een veelzijdig overzicht.

Het menselijke lichaam heeft vele dimensies. Dit wordt bijzonder duidelijk in de 20 hoofdstukken van dit boeiende en rijk geïllustreerde boek. Het beschrijft op caleidoscopische wijze zeer uiteenlopende visies over het lichaam. Tegelijkertijd biedt het de lezer een beknopte historische schets van de evolutie in de filosofie, van Plato over Thomas van Aquino naar Descartes en Hegel tot Nietzsche, Levinas en Sartre. Elk hoofdstuk is mooi geordend in 3 delen: een klinisch vignet of illustratie, een wijsgerige reflectie of achtergrond en ten slotte het doortrekken van deze filosofische strekking naar een functie of een beleving van het menselijke lichaam.

Dit werk is dus niet meteen luchtige lectuur. De lezer gaat er het best even rustig voor zitten, als er tijd is om de dingen te laten bezinken. Het boek laat zich niet in 1 ruk verslinden, maar is het makkelijkst verteerbaar per hoofdstuk. Die laten zich elk afzonderlijk lezen, ook zonder chronologische volgorde. Wellicht doen wij, als professionelen in de gezondheidszorg, er goed aan om ons denken over en ons handelen met de vele lichamen die ons zijn toevertrouwd af en toe te herbronnen. Zeker aanbevolen dus!

Johan Buffels

Redacteur TvGG 